\title{
Roles of KH. Abdul Wahab Sya'roni and Syaikh Ali bin Ahmad Basalamah in the Development of Thariqoh Tijaniyah in Jatibarang, Brebes, Central Java
}

\author{
Mustain Yusuf,,$^{*}$ Yety Rochwulaningsih, ${ }^{2}$ Singgih Tri Sulistiyono ${ }^{2}$ \\ 'SMA Negeri 1 Brebes \\ ${ }^{2}$ Master Program of History, Faculty of Humanities, Diponegoro University
}

*Corresponding Author: mustain1enha@gmail.com

Received:

1 December 2017

Accepted:

18 December 2017

\section{Abstract}

The main purpose of this article is to examine the roles of K.H. Abdul Wahab Sya'roni and Shaykh Ali bin Ahmad Basalamah in the development of Thariqoh At-Tijaniyah in Jatibarang Brebes, Central Java Province. This discussion is very interesting given that this thoriqoh is developing in the spreading area of other thariqoh that is Thariqoh Qoodiriyah Naqsyabandiyah. Therefore, its spreading faces some challenges. The spread of Thariqoh At-Tijaniyah in Jatibarang Brebes cannot be separated from the critical roles of Kyai Sya'roni and Shaykh Ali bin Ahmad Basalamah. In the beginning, these two ulamas pioneered the establishment and development of thariqoh which is not only bounded to Jatibarang Brebes but also widen to the neighboring areas, especially in the Northern Coast of Java (Pantura). Nevertheless, the next development of this thariqoh is centered in Jatibarang, Brebes. Regarding to this matter, the development of Thariqoh At-Tijaniyah especially in Brebes and the roles of these kyai will be discussed.

Keywords: Thariqoh At-Tijaniyah; Wirid; Ukhuwah Islamiyah; Tasawuf.

\section{Introduction}

Since the entry process to date, the history of Indonesia cannot be separated from the elements of Islam. Experts argue that Islamization in Indonesia is influenced by thoriqoh. Thoriqoh as a madhhab, method, or container of spiritual guidance to the individual in directing life to be closer with God, is an effective medium to spread Islam at that time (Baidhawi 2013). The opinion is also supported by the situation at that moment, the time of the spreading of Sufism (Thariqoh) to various parts of the world, while the Islamic Development ulamas in Indonesia are mostly adherents of thariqoh. They were originated from different regions, such as from Persia, India and Arab (Azra 2013: 51).

In the 21st century the development of thariqoh grows rapidly, there is 360 thariqoh across the world in 2010 (Munawir 2008; Masyhuri 2014); while in 
Indonesia, around 40 schools of thariqoh exists and eight well-known thariqoh with many follower including Thariqoh At-Tijaniyah which is developing well in Jatibarang Brebes.

Thariqoh At-Tijaniyah was founded by Sayyid Abdul Abbas Ahmad ibn Muhammad ibn Al Mukhtar At Tijani is thariqoh mu'tabaroh, which means sanad or genealogy thariqoh muttasil (connected) with the Prophet Muhammad. Besides mu'tabaroh as the main requirement, thariqoh have to fulfill other requirements, such as the material must be sourced from the Qur'an and Sunnah. Now the existence of Thariqoh At-Tijaniyah both in the world and in Indonesia is growing very rapidly, including in Jatibarang Brebes. Based on the above explanation, there are several issues to be studied: First, what exactly is Thariqoh At Tijaniyah? Second, how is the development process of Thariqoh At-Tijaniyah in Jatibarang Brebes? Third, how is the role of KH. Abdul Wahab Sya'roni and Shaykh Ali bin Ahmad Basalamah in the development of Thariqoh At-Tijaniyah in Jatibarang Brebes?

\section{Thariqoh At-Tijaniyah}

Thariqoh At-Tijaniyah was founded by Sayyid Abul Abbas Ahmad ibn Muhammad ibn Al Mukhtar At Tijani. Based on the patrilineal and matrilineal nasab, he comes from ulama family (Fauzan 2007: 11). Shaykh Ahmad At-Tijani is the 21st descendant of Prophet Muhammad SAW from the line of Sayyid Hasan, the first son of Sayyidah Fatima Al Zahra, daughter of Prophet Muhammad SAW. He was born in Ain Madhi or Madhawi, southern Maghribi of Algeria, Thursday 13 Shafar 1150 H / 1737 AD and died September 22, $1230 \mathrm{H} / 1815$ AD at the age of 80 in Faz, Morocco. Shaykh Ahmad At Tijani was from the (kabilah) Tijan big family who famously give rise to great ulamas (Basalamah and Anam 2011: 15).

In his childhood, Shaykh Ahmad At-Tijani has shown the signs - a sign of privilege and breadth of knowledge. He had been studied various sciences from various professors and Shaikh Thariqoh. When he was 7 , he was able to memorize the Qur'an in the Qira'ah of Nafi'u. Survived by his both parents at the same time when 16, it did not dampen his spirit in the scientific activities, teaching, writing, and giving fatwas, until in $1171 \mathrm{H}$, he stepped boldly to enter the world of Sufism (Basalamah and Anam 2006).

During the long journey of searching and practicing the sciences of the saint (wali) and visits to some Thariqoh Shaykhs resulted in a great deal of knowledge, wirid, and achievements. Some Thariqoh taken even granted with the permission to teach (mentalqin), but because of Inayah Robbaniyyah (guidance from Allah SWT) they were then abandoned except those taken directly from the Prophet Muhammad. The Thariqoh is Thariqoh Qadiriyyah, Thariqoh Nashiriyyah from Sayyid Abu Abdillah Muhammad bin Abdillah Al Nazani, Thariqoh Sayyid Muhammad Al Habib bin Muhammad $(1165 \mathrm{H})$. He then took the Thariqoh Malamatiyah diploma from Shaykh Abu Abbas Ahmad Al Tawwas in Tazih (w.18 Jumadal Al Ula 1204 H in Tazih).

In $1180 \mathrm{H}$ he took Thariqoh Khalwatiyah and various sciences from Sayyid Abu Abdillah Muhammad bin Abdurrahman Al Azhari (w. Beginnings of Muharram 
$1180 \mathrm{H}$ ) in Algeria (Basalamah and Anam 2011: 19-24). With all of his knowledge, in $1186 \mathrm{H}$ he departed from Tilmisan to perform Hajj and pilgrimage to the Prophet Muhammad. In the middle of the journey, he took a stop in Susah village-Tunisia for one year and made a good friend with Sayyid Abd Al Samad Al Rahawi (Mulyati 2011: 219).

When Shaykh Ahmad At-Tijani visited Shaykh Abu Samghun in a tranquil area of $90 \mathrm{~km}$ in south of Geryvile, Sahara Desert in 1196 AH / 1782 AD, while in seclusion (khlawat) he received a great grace from Allah SWT, that is Al Fath Al Akbar ${ }^{1}$, a face to face meeting with the Prophet Muhammad SAW in awake state or conscious (yaqzhah) (Basalamah and Anam 2011: 25). Since that meeting, Rosulullah SAW never lost from his sight and always with him.

Shaykh Ahmad At Tijani acknowledged when he received his fath, the Prophet Muhammad came and informed him that during this time he himself taught and guided him in thariqoh, so he did not need to feel indebted to any Tariqoh Shaykh. The Prophet Muhammad ordered to abandon all the Thariqoh he had been studied previously and hung onto this Tariqoh (Tijaniyah) and allowed him to establish his own Thariqoh. Prophet Muhammad teaches (mentalqin) about wirid that must be practiced in the form of reciting istighfar and Shalawat, 100 times each, without seclusion (retreat). In the next fath (1200 AH / 1786 CE) Prophet Mohammad (SAW) perfected the teachings of Thariqoh by giving additional wirid by reciting lafadz (tahlil) la ilaha illa Allah for 100 times. He confirmed that the Prophet Muhammad is his only Shaykh, therefore the followers of Shaykh Ahmad At Tijani called it as (At Thariqoh al Muhammadiyyah) Thariqoh Muhammadiyah (Masyhuri 2014: 354).

In Muharram $1214 \mathrm{H} / 1799 \mathrm{AD}$ at the age of 50 years, in Arafah Desert Makkah Al Mukaramah, Shaykh Ahmad bin Muhammad At Tijani confirmed has reached the dignity of Al Qutub Al Kamil, Al Qutubul Al Jami and Al Qutubul Al Udzhma. In the next few days on the 18th of Shafar 1214 H / 1799 AD, he was awarded as Al Khatmu Al Auliya Al Maktum (as the hidden last saints). This event is then regarded as the day of Id $\mathrm{Al} \mathrm{Khatmi}{ }^{2}$ by the followers of Thariqoh At-Tijaniyah (Basalamah and Anam 2011: 27-41).

The rapid development of Thariqoh At-Tijaniyah was considered to be able to compete with Ottoman rule, so Shaykh Ahmad At Tijani and his followers were expelled from Algeria. In $1213 \mathrm{H} / 1798 \mathrm{M}$ Shaykh Ahmad At Tijani moved the activity center and the spread of his thariqoh to Fez Morocco and with the help of the ruler of Morocco, Maulay Sulaiman, in 1800 a zawiyah was established in Fez for his settlement until he passed away in $1230 \mathrm{H} / 22$ September 1815 AD in the age of 80.

${ }^{1} \mathrm{Al}$ Fath Al Akbar is a great gift from Allah SWT in form of the opening of the blind separating between someone with Prophet Muhammad, the opening of the highest dignity of saint.

2 Quthub means the most beautiful star. The best human who collects all virtues, in human nature, worship, and his closeness to Allah SWT; also known as the Khalifah of Prophet Muhammad to maintain the balance of nature. Described in the book of Jawahir Al Ma'ani and Kanz Al Muthlasam, Qutubul Al-Kamil wa Al-Jami is the greatness of the physical and mental gift as well as the inner core by knowing ism al adham covering all forms, letters, pronunciation, number, purpose, and time, ism al adham may be taught and some are forbidden to be taught. 
Before he died, Shaykh Ahmad At Tijani had appointed Ali ibn Isa as Khalifah (muqodam zawiyah) who made Tilimsan-Algeria his center. He wishes that the order succession of Khalifah is done in turns between Ali ibn Isa family and At Tijani's family, so that after the death of Ali ibn Isa, the leadership went to Muhammad As Saghir ibn Ahmad At Tijani (1853 AD) with Ain Madi as the center. His next successor was Muhammad Al-Id ibn Ali ibn Isa (d 1876 AD). In the next period after Al Id, there was a dualism of leadership. Muhammad As Saghir (1892 AD) was appointed in Tilimsan, while Ahmad (1897 AD) was appointed in Ain Madi replaced by Al Basyir (1911 AD), then Ali. Although both groups of Thariqoh are separated, the muqodam of Thariqoh At-Tijaniyah are very active in making new branches.

The long-standing alliance with the Moroccan government since Maulay Sulaiman period is very crucial to approach At Tijani in order to face the competition with zawiyahs of the sharifs which are considered threatening his power, until the end of the 19th century. This makes the development of Thariqoh At-Tijaniyah is very rapid in Morocco. Based on such protection guarantee and cooperation, when Wahabiyah movement emerges which is hostile to Sufi and Thariqoh and grave pilgrimage tradition, Tariqoh At Tijaniyah is experiencing rapid development instead.

A strong alliance with At Tijaniyah until the issuance of the Protectorate declaration in 1912 made every city in Morocco have the opportunity to establish the Tijaniyah Zawiyah. This condition is pointed out as one of the reasons Thariqoh AtTijaniyah in Morocco grow faster compared to the origin of this Thariqoh, namely in Algeria and Tunisia (Mulyati 2011: 223). In addition, the development of Thariqoh AtTijaniyah in Morocco also cannot be separated from the role of Shaykh Muhammad ibn Ahmad Al Kansus (1877 AD). He has a big contribution in developing Thariqoh At-Tijaniyah in the south of Morocco.

Through the role of Muhammad Al Hafidz bin Al Mukhtar from Udwah Ali kabilah in Mauritania, this Thariqoh then spreads from Morocco to the southern part of Sahara. Accompanied by several people from his kabilah after meeting with Shaykh Ahmad At Tijani in 1789, he was appointed as muqadam and was given permission to spread the Thariqoh. The spread among negro was also supported by Umar ibn Sa'id Al Futi (1795 - 1864 AD) a Negro ulama from the Futa Toro region. Al Futi after receiving the teachings of Thariqoh for one year from Shaykh Abdul Karim ibn Ahmad Al Mughili Al Futajaluni, was very active in teaching and spreading Thariqoh At-Tijaniyah in surrounding cities such as Kangaba, Koumbiya, Diagonko, to outside Nigeria. The fruit of his labour is the book of Ar Rimah containing the fundamental of Thariqoh Tijaniyah and Rimah Hizb Ar Rahim al Hizb ar Rajim which was written in $1261 \mathrm{H} / 1845 \mathrm{AD}$.

The spread from west Africa to Egypt was introduced by Umar Janbu, a disciple of Muhammad As Saghir ibn Ali At Tilimsani, the grandson of Ali ibn Isa. Around 1900 AD, Thariqoh At-Tijaniyah also widely spread to Sudan and Sinegal, which was first adhered by the Moorish tribe. The next development in 1925 AD, Shaykh Alfa Hashim, an At Tijani muqodam from west Africa visited Sudan, 
followed by Shaykh Ad Dardabi Al Maghribi, so that many people embraced this Thariqoh (Masyhuri 2014: 256-357).

In early 20th century, Thariqoh At-Tijaniyah continued to spread to various regions of Africa, such as Sinegal, Mauritania, Guinea, Nigeria and Gambia, even to Asia such as Saudi Arabia and Indonesia. Through the influence of Al Haj Yusuf brought during a visit to Makkah and the results of study from Shaykh Alfa Hashim in Medina, the development of Thariqoh At-Tijaniyah can spread to East Africa such as Ethiopia and Somalia. Meanwhile, Shaykh Muhammad ibn Malik Al-Ilmi (1943 AH), and Shaykh Al-Basyir (1911 AD) were contributing a lot in the distribution of Thariqoh outside Algeria, that is to Egypt, Sudan, Syria, Palestine and Turkey. In 1924 Al Ilmi founded a zawiyah in Medina; while in 1951 an Egyptian muqodam Shaykh Muhammad Al-Hafidzh ibn Abdul Latif founded the Thariqul Haq magazine as the media of distribution (Yusuf 1985).

The rule of Thariqoh At-Tijaniyah in the position of muqodam (tariqah teacher) cannot be achieved because of appointed or requested by a person but based on isyarah since the position of muqodam is essentially a gift from Allah SWT to the chosen one. However, asking to learn and asking for bai' at to become a member of (Ikhwan) Thariqoh At Tijaniyah ${ }^{3}$ is highly recommended. In general, muqodam is someone who has learned a lot of knowledge of dzahir like tafseer, hadith, fiqih, kalam, tsawuf and other knowledge related to Islamic shari'a (Masyhur 2014).

The practice is also categorized as the lightest, because the wirid only takes five minutes every morning and evening. This wirid is called wirid wa'difah, and then ba'da magrib or isya between 15 -30 minutes. Also the wirid practiced once a week called hadroh khasiatul jum'ah. There are three types of wirids, namely (1) Wirid Lazimah practiced in the morning and evening (Istighfar, Hailallah, Sholawat $100 \mathrm{X}$ ); (2) Wirid Wadifah practiced when maghrib or Isya; (3) Wirid Khasiatul Jum'ah.

Based on the available information, it can be seen that Thariqoh At-Tijaniyah is one of Thariqoh Mu'tabarah which is experiencing a very rapid development. The book about the history of this Thariqoh as well as its zikir as a reference for anyone who wants to learn it has been written by the teachers of Tijaniyah in Jawahir Al Ma'ani wa Bulugh Al Amaniy fi Faidl Al Sheikh Al Tijaniy or known as Al Kana ' is.

\section{The Distribution of Thariqoh At-Tijaniyah In Jatibarang, Brebes}

The entry of Thariqoh At Tijani to Jatibarang Brebes is closely related to the entry of Thariqah At Tijani to Indonesia (Hidayat 2005). It was identified that there are two ways which begin Tariqoh Tijaniyah movement in Indonesia, namely, the presence of Shaykh Ali Thayib, and secondly, the teaching of Tariqoh thariqoh in Pesantren Buntet Cirebon which was brought directly by Kyai Anas from the holy land of Mecca (https://4binajwa.wordpress.com/khazanah-tijaniyah/perkembangan-tarekattijani-di-indonesia). The two means clearly influence the facts about the existence of Tariqoh Tijaniyah in Jatibarang, both of which are an integral part of Jatibarang

3 KH. Ahmad Said Basalamah (Muqodam Thariqoh At Tijaniyah), interview 14 December 2014. 
ulama, Kyai Sya'roni and Shaykh Ali, since Shaykh Ali Thayib and Kyai Anas have a good personal relationships with both Jatibarang ulamas (Fakhrudin \& Basalamah 2009). This also affirms the fact that Kyai Sya'roni and Shaykh Ali are the pioneer and developer of Thariqoh At Tijani in Jatibarang Brebes. Kyai Sya'roni and Shaykh Ali were good friends with Kyai Khawi (Buntet Cirebon), so when Shaykh Ali deceased, Kyai Khawi who appointed Shaykh Muhammad Basalamah (the sole son of Shaykh Ali) as Muqodam At Tijani in Jatibarang succeeded his father. ${ }^{4}$

Now all the activities of Thariqoh At-Tijaniyah in Jatibarang are entrusted to K.H. Rosidi Malawi Sya'roni and Shaykh Soleh bin Muhammad Ali Basalamah who are the charismatic Kyai Jatibarang who always guide and monitor the development of Thariqoh At-Tijaniyah in this area. He is the Muqodam of Thariqoh At-Tijaniyah from the third generation of K.H. Abdul Wahab Sya'roni and Shaykh Ali ibn Ahmad Basalamah.

The development of Tariqoh At Tijaniyah in Jatibarang Brebes reached its peak in 2005 when Jatibarang was trusted to be the place of Halaqoh of the International Alim Ulamas and Idul Khotmi At Tijani attended by national and international Alim Ulamas. Vice President of the Republic of Indonesia, Muhammad Yusuf Kalla, and a lot of Muslims attend the event (Idul Khotmi Lil Qutbil Maktum Syaihk Ahmad At Tijani 2005).

\section{The Role of KH. Abdul Wahab Sya'roni and Shaykh Ali Basalamah}

Assessing the existence and development of Thariqoh At-Tijaniyah in Jatibarang Brebes cannot be separated from the important role of Kyai Sya'roni and Shaykh Ali, because they are the pioneer of the establishment and development of thariqoh which is not only limited in Jatibarang Brebes but to some other areas especially in the North Coast of Java (Pantura). Regarding the entry of Thariqoh At Tijani to Jatibarang Brebes, it was brought by Shaykh Ali Thayib from Mecca around 1921. Shaykh Ali Thayib stayed in Raden Mas. H. Wangsa residence (one of the employees / managers of Jatibarang Sugar Factory), the parents of Raden Mas H. Ali Afandi, one of Islamic activist in Jatibarang, located 50 meters away from the west of Kyai Sya'roni's residence. Therefore, it is possible that Shaykh Ali Thayib then entrusted the establishment of Thariqoh At-Tijaniyah in Jatibarang to Kyai Sya'roni. ${ }^{5}$

In developing Thariqoh At-Tijaniyah in Jatibarang Brebes, Kyai Sya'roni and Shaykh Ali prefer the soft ways through personal approaches began with their closest people such as neighbors, relatives, friends, best friends, and etc. They spread their teachings with their own ways by delivering tausiah and recitation in various places starting in their own homes, in mushollas and mosques in their neighborhood and then widen to their village environment, to several villages, sub-districts and districts. On various occasions, giving tausiah and recitation was always delivered with the teachings of Shaykh Ahamd Al Tijani, the founder Thariqoh At Tijaniyah,

4 Interview with Sholeh Muhammad Basalamah (supervisor of Pondok Pesantren Darussalam Jatibarang and grandson of Syaikh Ali), 8 December 2014.

5 Interview with Syaikh Sholeh Muhammad Basalamah (supervisor Pondok Pesantren Darussalam Jatibarang and grandson of Syaikh Ali), 8 December 2014. 
accompanied by certain religious movements that attract the attention of his followers or his students. Thariqoh At-Tijaniyah teaching in Jatibarang was developed by Kyai Sya'roni and Shaykh Ali lend color to the development of tasawuf at that moment, so that Thariqoh At-Tijaniyah can quickly develop even outside Jatibarang.

Despite its development, Kyai Sya'roni and Shaykh Ali were also facing many obstacles, especially from other schools in Islam since the teachings in Thariqoh AtTijaniyah are considered mystical and often seen as a cult in Islam. However, essentially this tariqoh teaches devoutness (alim), wara, and wisdom as the followers of Islam. Facing various negative views on this Thariqoh At Tijaniyah, it was explained since the beginning that the founder of Thariqoh Shaykh Ahmad At Tijani stated that Thariqoh At Tijani would face trials in form of disowning of many people, so that the followers of thariqah must be patient because of these trials. The condition became more conducive when Thariqoh Tijaniyah is acknowledged as a part of thariqoh mu'tabarah which is recognized by the NU ulamas. This is reflected from congressional decision ( $6^{\text {th }}$ Keputusan Muktamar of NU in Cirebon in August 1931 led by KH. Hashim Ash'ari, stated that Thariqoh Tijaniyah with all forms of its practice is declared as mu'tabarah or Shah. ${ }^{6}$

The development of Thariqoh At-Tijaniyah in Jatibarang reached its peak which marked by Idul Khotmi event along with the inauguration of Al Ittihad Mosque on March 3, 2005. This event was an important event of the development of Thariqoh AtTijaniyah in Jatibarang Brebes, because it was the first event which successfully presented the muqodam / important figures of Tariqah At Tijaniyah from South Africa, such as Shaykh Fakhrudin. In the previous year, Shaykh Soleh Basalamah (grandson of Shaykh Ali) was invited twice in the same event in South Africa and the event was significant to the development of Thariqoh At-Tijaniyah in general and in Jatibarang Brebes in particular.

\section{Conclusion}

Thariqoh as a madhhab, method, or container of spiritual guidance to the individual in directing life toward the closeness with God, is an effective medium to spread Islam. In its implementation, thariqoh must fulfill several requirements, that is mu'tabaroh means thariqoh sanad must be connected to the Prophet Muhammad. Moreover, all teaching materials must be sourced from the Qur'an and Sunnah.

Thariqoh At-Tijaniyah founded by Shaykh Ahmad At Tijani is thariqoh mu'tabaroh. Its existence is recognized and developed rapidly in Indonesia. The history and teachings of Thariqoh At-Tijaniyah have been completely written by the teachers of tariqoh in the book of Jawahir Al Ma'ani wa Bulugh Al Amaniy fi Faidl Al Shaykh Al Tijaniy or known as book of Al Kana'is.

Thariqoh At-Tijaniyah process of entering and growing in Indonesia relates to its entering process in Jatibarang Brebes, between the 1920s. Its existence and

${ }^{6}$ Decision in Muktamar NU also supported by influencing Ulama in NU such as KH. Wahab Hasbullah and KH. Ma'sum from Lasem. An interview with KH. Ahmad Said Basalamah (Muqodam Thariqoh At Tijaniyah), 14 December 2014. 
development cannot be separated from the role of KH. Abdul Wahab Sya'roni and Shaykh Ali Basalamah. These two figures are the first to pioneer and develop Thariqoh At-Tijaniyah in Jatibarang Brebes and surrounding areas. Today, the continuity of this Thariqoh is preserved by KH. Rosidi Malawi Sya'roni and Shaikh Soleh Muhammad Ali Basalamah as the direct descendants and their students as well.

\section{References}

Azra, Azyumardi (2013). Jaringan Ulama Timur Tengah Dan Kepulauan Nusantara Abad XVII \& XVIII Akar Pembaruan Islam Indoesia. Jakarta: Kencana Prenada Media.

Baidhowi Baa Syaiban Umar Syaikh (2013). Manaqib Thariqoh At-Tijaniyah Hagiografi Khotmul Auliya al-Qutb al-Maktum Syaikh Ahmad at-Tijani RA dan Ajaran Thariqohnya. Jakarta: PT. Pustaka Akindo.

Basalamah, Sholeh, and Misbahul A. (2006). Tijaniyah Menjawab Dengan Kitab dan Sunnah. Tangerang: Putra Bumi.

Fakhrudin, Ahmad Al Uwaisi, and Muhammad S. Basalamah (2009). Syekh Ahmad Attijani R.A keturunan Rosulullah Yang Mirip Rosulullah SAW (Jatibarang: PP. Darussalam.

Fauzan Adhiman Fathulah (2007). Thariqoh Tijaniyah Mengemban Amanat Rahmatan Lil'alamin. Banjarmasin: Yayasan Al Anshari.

Hidayat, Muhamad Nur (2013). Tarekat Dalam Timbangan Syariat. Surabaya: Muara Progresif.

Masyhuri Aziz.A. (2014). Ensiklopedi 22 Aliran Tarekat Dalam Tasawuf. Surabaya: Imtiyaz.

Mulyati, S. (2011). Mengenal Dan Memahami Tarekat-Tarekat Muktabarah di Indonesia Jakarta: Kencana Prenada Media Group.

Munawir, Abdul Fatah (2008). Tradisi Orang-Orang NU. Yogyakarta: Pustaka Pesantren, 2008.

Soleh Basalamah and M. Anam. (2011). Tijaniyah Menjawab Dengan Kitab dan Sunnah. Tangerang: Putra Bumi.

Yusuf, Abdullah Puar (1985). Masuknya Islam Ke Indonesia. Jakarta: CV. Indrajaya.

“Laporan Panitia Idul Khotmi Lil Qutbil Maktum Syaihk Ahmad at Tijani 2005".

https://4binajwa.wordpress.com/khazanah-tijaniyah/perkembangan-tarekat-tijani-diindonesia, accessed on 17 January 2016. 